\title{
Factors influencing climate change adaptation strategies in North-Western Ghana: evidence of farmers in the Black Volta Basin in Upper West region
}

\author{
Francis X. K. Mwinkom² Lawrence Damnyag $^{1}$ (1) $\cdot$ Simon Abugre $^{2} \cdot$ Suhiyini I. Alhassan $^{3}$
}

Received: 13 July 2020 / Accepted: 12 March 2021 / Published online: 12 April 2021

(c) The Author(s) 2021 OPEN

\begin{abstract}
The erratic rainfall patterns and decline in crop production are due to the threat of climate change. The responses of farm households to climate change play a very essential role in addressing the risk of climate change. This study investigated factors influencing adaptation strategies to climate change in the Black Volta Basin of Ghana. Survey questions were administered to 450 households sampled from eight districts using a multistage sampling technique. Out of the six adaptation strategies, four major identified adaptation strategies were subsequently used as the dependent variable in the multivariate (MV) probit and binary logit models. The results revealed that factors such as gender, age, household size, farmer-based-organizations membership, farm income, years of education, districts of location of respondents, farm size and climate change awareness_-statistically and significantly_influenced households' adaptation to the changing climate. However, the positive correlation matrix from the MV probit model showed complementarities among all the adaptation strategies adopted by household heads. Priority should be given to improving household heads' adaptive capacity. Also, governmental and non-governmental organizations should invest in climate-resilient programmes. Finally, programmes aimed at sensitizing household heads on climate change adaptation strategies such as changing planting time, changing farming methods, and planting early maturing and drought-resistant varieties through pieces of trainings and workshops may be duly supported by the Government; particularly, for household heads in the Black Volta Basin.
\end{abstract}

Keywords Adaptation strategies · Black Volta Basin · Logistic regression · Crop farmers · Climate change

\section{Introduction}

Climate change has become a global concern to farmers, especially to those in tropical regions like Africa [1-4]. The adverse effects of climate change on agriculture are evident in Africa, and attention needs to be given to avert this situation. Farmers in sub-Saharan African (SSA) countries are those severely affected by the adverse effects of current climate changes. [5] found that climate change is actually a new normal. In the face of an ever-increasing population, anthropogenic activities continuously trigger changes in climate. Relevant researches have demonstrated the vulnerability of Africa to climate change as a result of poor government agricultural policies, inadequate technology, poverty, weather extremes and economic challenges [6]. Other studies have revealed educational, financial, technological, institutional and

Supplementary Information The online version contains supplementary material available at https://doi.org/10.1007/s42452-021-04503W.

$\triangle$ Lawrence Damnyag, Idamnyag@yahoo.com | ${ }^{1}$ CSIR-Forestry Research Institute of Ghana, Kumasi, Ghana. ${ }^{2}$ Department of Forest Science, University of Energy and Natural Resources, Sunyani, Ghana. ${ }^{3}$ University for Development Studies, Tamale, Ghana. 
socio-cultural barriers as some factors that increase the vulnerability of farmers to climate change in Africa [6-8].

As many studies have been conducted on climate change adaptation in other regions such as Australia, Canada, the USA, Europe, and parts of Asia, Africa is still grappling with good study on adaptation barriers hindering the implementation of adaptation strategies $[8,9]$.

Climate projections from existing data have shown that prolonged and more intense droughts are likely to cause intense dryness in SSA by $2040[5,7,10]$. Other studies have revealed that determining appropriate adaptation strategies for climate variability in SSA is challenging due to the different biophysical obstacles associated with geographical location [11]. Therefore, climate change repercussions such as high temperatures, food insecurity, prolonged drought and pest should be handled using pragmatic and perceived adaptation strategies. Despite climate change perceptions not being consistent with certainty, it could be a useful part of a solution. Further, studies have revealed a significant change in temperature in West Africa between $0.5^{\circ} \mathrm{C}$ and $0.9^{\circ} \mathrm{C}$ from 1990 to 2010 and predicted an increase in this magnitude by 2050 [12]. In Ghana, a related study by [13] based on downscaled climate scenario revealed projected temperature trends spanning 2010-2050 showed warming entirely in Ghana with specifically peaking temperatures for the Northern, Upper West and Upper East regions and further projected the temperature rise ranging $2.1-2.4^{\circ} \mathrm{C}$ by 2050 . Similarly, another study has proven that intense droughts in northern Ghana have resulted in unseasonably high temperatures, poor soil water retention capacity and soil infertility [14], leading to poor agricultural productivity. The northern part of Ghana which, nationally, produced approximately $40 \%$ of legumes and grains in the last two decades currently produces less than $25 \%$ [15]. The application of fertilizer as a way of reducing the detrimental effects of climate change in the region has not shown satisfactory results.

Moreover, comparing rural inhabitants in other regions to that of the three regions, the latter in the mentioned regions are more deserted to climate change due to the regions' stacked development and the dry land agriculture's vulnerability to climatic stresses $[16,17]$.

Regardless of this, almost all ongoing climate change initiatives in Ghana are largely at the national level and fail to target specific sectors such as the agricultural sector. Although climate change is known to be a physical process involving changes in climatic variables, it can affect social processes that are associated with how society evolves through time. Climate change can impact socio-economic and environmental systems and shape the prospects for energy, food, water and health security [12].
For instance, the study conducted by [18] focused on the vulnerability of local communities in Ghana to climate change. The results of the study indicated that socio-economic factors influencing vulnerability to climate change include household size, climate change information accessibility, climate-sensitive jobs and income diversification. [19] also assessed farmers' adaptation strategies employed by the Sisaala tribe in the Upper West Region of Ghana. The assessment revealed that agroforestry practices, irrigation, use of virgin lands, drought-resistant crops and mulching were preferred to other methods. However, for policies to be well informed, these results are inadequate. This is because the authors failed to employ rigorous statistical methods to measure the implications of socio-economic factors that influence climate change.

A number of current studies [20-22] on climate change adaptation choices and technology adoption assume that farmers consider a set of possible practices and select a specific bundle that maximizes expected utility. Thus, the choice of adoption is inherently multivariate and trying a univariate approach eliminates relevant economic data confined in interdependent and simultaneous adoption choices. Based on this argument, the study employed MV probit model to concurrently assess the effect of the set of explanatory variables on key adaptation strategies [23-25].

One major pitfall of most previous studies on analytical choice of climate change adaptation strategies is that no consideration is given to the possible interrelationships found between the different adaptation strategies [26]. Most farmers are, by nature, more likely to employ a mix of adaptation strategies to handle the various climate-change-induced constraints and risks than a single strategy. The reality faced by farmers is, however, masked by most previous studies as they fail to consider farmers challenged with alternatives that may be employed concurrently and/or sequentially as supplements, substitutes or complements.

Farmers must have been informed about climate change from the genesis of its temporal and prolonged scales of impact varying across different farmer locations. The nature of a given scenario of climate change at a location relies on the extent of these variations, specific crop feedbacks, and site-tailored management practices.

Many climate change indicators are reported in the literature even though there are variations with location [27-32]. Farmers may thus be aware of climate change, but the degree of awareness of its short- and long-term causes and consequences may vary among the farmers.

Several reports in Ghana have expressed disparities in households' responses to adaptations concerning climate change and variability. These disparities span across maintenance of subsistence production systems, sales of 
household assets, household migration, reducing food consumption, changing planting dates, utilizing drought tolerant crop varieties, indigenous knowledge based conservation practices, application of weedicides and insecticides, row planting, crop rotation, mixed cropping and other socio-economic factors [33-36]. The poor crop and fish farmers who are direct environment dependants are highly probable to exposing their livelihoods to undue hardship attributable to the rigors of severe climate effects. Integrating farmers' opinions into adaptation planning is crucial as empirical studies propose that the hostile impacts of climate change on agriculture will be experienced unevenly within the country [37]. Therefore, it is critical for farmers to undertake adaptation strategies to help cushion them against the hostile impacts of climate change.

Based on the principle that there will be complementarities and/or substitutability between different strategies, this study is, therefore, aimed at assessing the factors influencing climate change adaptation strategies in North-Western Ghana as evidenced by farmers in the Black Volta Basin in the Upper West region.

\section{Climate change and adaptation strategies of food crops}

Ghana falls within the tropical zone and is gradually witnessing the effects of climate change on its agriculture. The study of [38] revealed that climate change is clearly experienced in the North-Western part of Ghana. Farmers in the northern part of Ghana (which includes Upper East, Upper West, Northern, and some parts of Bono, Ahafo, and Oti regions) are likely to be the most affected due to the severe weather conditions which are experienced in those areas. [39] and [40] noted that the period of planting for crops in northern Ghana has changed from early April 1960 s to late April or early May in recent times due to the unpredictable nature of precipitation and the changing environmental conditions, especially rainfall amounts and distribution. Therefore, smallholder farmers in the northern part of Ghana are expected to witness more of the adverse effects of climate change. This is largely because farmers in these regions lack the capacity to sufficiently adapt to climate change.

Despite this, mulching, farming on fallowed land, planting early maturing crop varieties and the use of fertilizers are ways some farmers in northern Ghana use, with the main goal of alleviating the impacts of climate change on agricultural productivity [41]. The adoption of an adaptation strategy by a farmer is influenced by their expectation about the feasible benefits that may be generated in future. Thus, there is a certain cost attached to the adaptation to climate change. This is the cost [42] termed as the "traditional cost". The application of a specific adaptation strategy can be associated with so many factors. Those unknown factors become the determinants of the choice of the various adaptation strategies that farmers use in reducing the impacts of climate change on agricultural productivity.

Farmers' decision to adopt an adaptation strategy to reduce the impacts of climate change relies largely on some socio-economic parameters which must be known. These parameters are significant in formulating policies to support effective and efficient adoption in the agricultural sector. The adoption of the adaptation strategy may vary from farmer to farmer depending on land and farm management practices, farmer socio-demographic features, livelihood strategies and farm characteristics. The understanding of the way several components of these parameters influence farmers' decision to select a specific adaptation strategy is very significant, considering the choice of livelihood strategies prevailing in northern Ghana. Knowing the factors that influence the choice of an adaptation strategy is important in the formulation of interventions on those key parameters perceived to enhance farmers' adaptive capacities [9].

Efforts by the Ministry of Food and Agriculture (MOFA) and other related research institutions in Ghana in proposing interventions such as agroforestry, crop diversification, livestock rearing and drought-resistant crops as strategies to combat the effects of climate change have not sufficiently addressed the poor conditions in the region [7]. Moreover, the attempts by government, non-governmental and international organizations (NGOs) to address the effects of climate change in SSA have stimulated some farmers to adopt strategies to reduce soil temperature, improve soil fertility and conserve soil moisture. As farmers have ways of employing their own strategies to alleviate the impacts of climate change on livelihood, adaptation awareness has already been introduced to Africa. Adaptation is, therefore, the adoption of strategies by vulnerable farmers to mitigate the detrimental effects of climate variability and change on livelihoods and ecosystems [12].

International organizations' and local stakeholders' efforts to tackle climate change have incorporated adaptation strategies as formidable policies to address food insecurity, extreme poverty, hunger and other effects related to climate variability [18]. Also, viable existing adaptation strategies could be aligned with new adaptation strategies that have the propensity to enhance the environment in the short-run for the benefit of farmers [5-10]. Therefore, adaptation strategies and constraints need to be supported by empirical data from farmers to enhance the clear difference between the realities and perceptions 
of climate change. Thus, the wellbeing of farmers could be enhanced if the adaptation experiences of farmers form a significant part of climate change policy.

\section{Materials and methods}

\subsection{Study area}

The Black Volta Basin (BVB) areas lie between latitude $7^{\circ} 00^{\prime} 00^{\prime \prime} \mathrm{N}$ and $14^{\circ} 30^{\prime} 00^{\prime \prime} \mathrm{N}$ and longitude $5^{\circ} 30^{\prime} 00^{\prime \prime} \mathrm{W}$ and $1^{\circ} 30^{\prime} 00^{\prime \prime} \mathrm{W}$. It covers an estimated area of about $130,400 \mathrm{~km}^{2}$ which constitutes about 21 per cent of the entire Volta basin area [19]. However, the Ghanaian portion of the basin area covers $18,384 \mathrm{~km}^{2}$, constituting 14 per cent of the total basin area [19]. Administratively, the basin comprises ten (10) districts in Ghana, fourteen (14) provinces in Burkina Faso, two (2) departments in Cote $d^{\prime}$ Ivoire and three (3) regions in Mali [20]. It covers about $1350 \mathrm{~km}^{2}$ from Burkina Faso to the Volta Lake with thirteen (13) main tributaries and accompanying catchment draining into the Black Volta river [19]. The banks of the BVB area are mostly used for agricultural production by the communities that are closer to the Basin.

The study was undertaken in eight districts that fall within the Basin. These districts are Lawra, Nandom, Wa West, Wa East, Wa Municipal, Lambussie-Karni, Jirapa, and Nadowli-Kaleo (see Fig. 1). Generally, annual rainfall in these districts falls between 800 and $1000 \mathrm{~mm}$, and average annual temperature ranges from $28^{\circ} \mathrm{C}$ to $37^{\circ} \mathrm{C}$. These districts experience a unimodal rainfall pattern yearly between April and July, with few showers from August to October. Moreover, these districts are dominated by high population of drought-resistant trees such as shea, dawadawa, baobab and few mahoganies.

Large portions of the natural ecological zone have been modified by anthropogenic activities in the pursuit of human livelihood. As a result, food crops such as rice (Oryza sativa), millet (Sorghum bicolor), maize (Zea mays), yam (Dioscorea spp.), groundnut (Arachis hypogea), beans (Phaseolus vigna spp.) and cassava (Manihot esculenta) are mostly cultivated. Farmers also grow

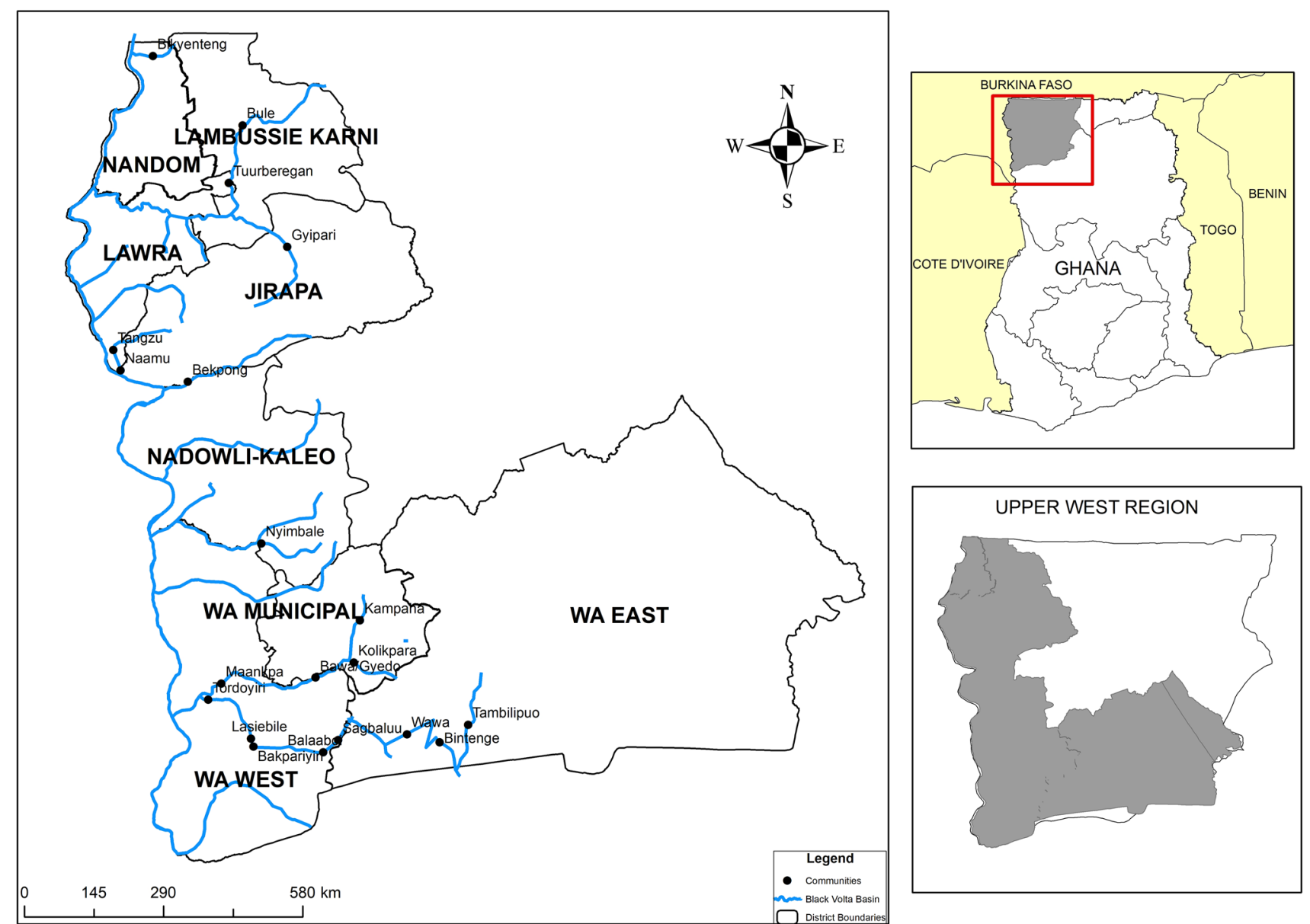

Fig. 1 Map of Ghana showing the district capitals and the selected communities for study along the BVB 
vegetables in the dry season and these include cabbage (Brassica oleracea), tomatoes (Lycopersicon esculentum), okra (Abelmoschus esculentus) and lettuce (Lactuca sativa) [21]. Generally, livestock grazing is done on the free-range with some herdsmen migrating in search of greener pasture and water in neighbouring communities [19]. Therefore, agriculture is the main source of livelihood for majority of the local people in these districts. Apart from farming, some of the local people are into alternative livelihoods such as hunting, logging and charcoal production.

\subsection{Sampling and data collection techniques}

A household farmer survey was undertaken from July to August 2018. A face-to-face interview was used with the aid of semi-structured questionnaires to collect primary data from 450 household heads in the BVB (Table 1). The number of farming households selected from each community and district was determined using a proportionate sampling technique. Proportionate sampling was employed because of the households that are largely different in number. Therefore, the number of households is determined by their relative number to the entire population. Also, the farming communities and districts were selected because they form part of northern Ghana where harsh or extreme weather conditions are experienced. However, the selection of the sample size was based on the fact that there are no records on the number of farmers in any region [9]. Therefore, this resulted in the selection of forty (40) farming communities from the eight districts using the simple random sampling technique.

A total of 450 household heads were sampled (Table 1). Household heads were selected for the survey due to the system that regulates land ownership and land security that varies largely across regions [43-45, 47]. Approximately, $84 \%$ of the total household heads were male. This is in line with the descriptive statistics of [9] and

Table 1 Sample size by district

\begin{tabular}{lrrl}
\hline District & Population & No. of households & $\begin{array}{l}\text { Sampled } \\
\text { households }\end{array}$ \\
\hline Nandom & 46,040 & 7417 & 33 \\
Lawra Municipal & 100,929 & 16,617 & 73 \\
Lambussie-Karni & 51,654 & 7524 & 33 \\
Nadowli-Kaleo & 94,388 & 15,210 & 67 \\
Jirapa Municipal & 88,402 & 13,911 & 61 \\
Wa Municipal & 107,214 & 18,891 & 83 \\
Wa West & 81,348 & 11,486 & 51 \\
Wa East & 72,074 & 10,768 & 48 \\
Total & 642,049 & 101,824 & 450 \\
\hline
\end{tabular}

Source: GSS, 2012
[20] where $81.94 \%$ and $83 \%$ of the majority were males, respectively. Therefore, the bias of the data towards men was unplanned. However, this was expected due to the sampling of household heads who were likely to be men and major decision makers [46]. Farmer gender studies [27, 47] also emphasized unequal allocation of assets between men and women in rural households, which favour or compel their adaptive capacities. [48] in a similar study of ecologically homogenous settings in India, Nepal and Bangladesh where there was a prevailing male-dominated pattern of access and ownership to productive assets like land selling/lease decisions, women play a weak role in agricultural decision making. Generally, in Ghana, land ownership lies largely in the hands of male $[49,50]$. Therefore, women who are smallholder farmers do not farm on their own lands but do so on lands owned by their husbands or household heads who are largely dominated by men. It is only a few women who have their own lands [50]. 51] further revealed that majority of household heads in South Africa are males. Thus, women only have access to land through their husbands. [52] noted that, in northern Ghana, lineage is strictly patrilineal; therefore, women do not have the right to 'own' land let alone pass it on to their children. The study by Fortes in the 1930s as cited by [52] noted that men, as head of the compound, organize the use of land under their own control in northern Ghana. The cultural restriction on women affect their wellbeing and existence as they are neglected and marginalized in decision making and policy developments concerning climate change [53].

The basis of using the respondents (household heads or their representatives) was vital to this study because it enables soliciting of information from participants who are knowledgeable in the subject under study [54]. The household head is an adult who has years of farming experience, indigenous knowledge or expected to perceive climate variability and changes and its impacts over time as highlighted during the household questionnaire survey. This approach is crucial towards augmenting the probability of practicing various adaptation strategies to climate change.

The questionnaires were administered to household heads or their representatives in the selected households. The representatives, here, are the divorced women or wives of deceased husbands. Culturally, headship position is a setaside responsibility more for males. Mostly, females undertake household headship position at instances when no adult male is present as a result of divorce, the demise of a husband or when the husband or adult male has embarked on a prolonged journey outside the community. But there were few instances where both husband and wife were sampled. This was so because in certain cases women also had their own farms and were major decision-makers of these farms and therefore qualified as respondents. Such women 
were considered in the sample since gender sensitivity was not a chief theme of the study and therefore was to ensure involvement by women farmers. Selected households were visited on different dates (Table 2) to explain the rationale of the study and seek their consent and the time convenient for them for the questionnaire administration.

\subsection{Theoretical model}

Farmer households decide to adopt an adaptation strategy to maximize their expected utility. The utility of a farmer's household is a function of anticipated adoption cost and benefits as well as their preferences that are influenced by several factors. Adaptation strategies serve as a measure of protection that decreases the farmers' risk of exposure by reducing the marginal effect of climate change on productivity [55]. The study employed the utility maximization theory in the presence of risk to conceptualize the adaptation decisions of climate change by a farmer. In this event, the definition of the utility to a farmer is not higher yields. In the adaptation context, the utility attained from adopting a strategy could stabilize yield and the implied decrease in risk. A risk-averse farmer household increases utility by selecting an adaptation strategy if the difference between the benefits and costs of adaptation is higher than the benefits derived without adapting. A farmer's utility function is defined by [56] as follows:

$Q_{y}=A_{y}-\alpha \omega_{y}$

where $Q_{y}=$ the perceived utility from selecting an adaptation strategy $y, A_{y}=$ the non-stochastic element, $\omega_{y}=$ the disturbance component showing a change in yields, $a=$ is a coefficient capturing risk aversion of specific farmers that would affect the degree of change in the yields $\omega_{y}$. The coefficient is expressed by [57] as:

Table 2 Summaries of districts and the dates of entry

\begin{tabular}{ll}
\hline District & Visit date \\
\hline Nandom & 24 July, 2018 \\
Lawra & 28 July, 2018 \\
Lambussie-Karni & 29 July, 2018 \\
Jirapa & 31 July, 2018 \\
Nadowli-Kaleo & 1 August, 2018 \\
Wa Municipal & 4 August, 2018 \\
Wa East & 6 August, 2018 \\
Wa West & 8 August, 2018 \\
\hline
\end{tabular}

$\alpha=\frac{-\left(\frac{\partial U}{\partial \omega \gamma}\right)}{\left(\frac{\partial U}{\partial \gamma}\right)}$

where, if $a<0$, the farmer is a risk-averse and, thus, is of high probability to adapt; $\alpha=0$ shows a risk-neutral farmer; and $a>0$ shows a risk-preferred farmer. The utility of implementing a specific adaptation strategy $y(U y)$ is given by the income attained by the adaptation strategy less than the variable costs borne in the adaptation strategy implementation. Given the options of adaptation strategies, a risk-averse farmer will select the adaptation strategy-for instance, $X$-that produces higher anticipated utility than the alternatives-for instance, $Y$ :

$E\left(U_{x}\right)-M_{x}>\left(U_{y}\right)-M_{y}$

where $\left(U_{x}\right)$ is the anticipated utility of implementing strategy $X$ and the related costs $M_{x}$, while the second component $U_{x}$ is the anticipated utility of implementing an adaptation strategy $Y$ and related cost $M_{y}$. Assumptions about the interaction of disturbance terms of the adaptation equation centres on, whether there is a correlation or not. This determines the type of qualitative choice model to use in the analysis.

\subsection{MV probit model}

When the adverse effects of climate change become intense, farmer households may opt to adopt several strategies as a measure of mitigation instead of relying on one strategy to exploit substitutability or complementarities among alternatives. Thus, in addition to relying on a specific adaptation strategy, a farmer household may select other adaptation strategies. The adoption processes could be partially dependent on earlier adopted strategies, influencing decisions on previous adaptation practices in the future $[58,59]$. Contrasting to other modelling methods like multinomial logit regression and univariate logit response, the study employed an MV probit model as appropriate because it concurrently models the estimated effect of the set of explanatory variables on each of the adaptation strategies while enabling the unobserved and unmeasured variables (error terms) to be orderly correlated freely $[48,49,59,60]$. Hence, the evaluations of multinomial logit or separate univariate probit equations are biased and inept in the presence of such correlations [50,51]. Specifically, MVP regression outspread the error terms which have a multivariate normal distribution, each with zero mean and variance-covariance matrix, where variance and covariance allow for such correlation [52]. 
The source of correlation may be substitute abilities and complementarities representing negative and positive correlations between the various adaptation strategies [53]. The MV probit model was developed following [54]. Several research findings have extensively employed MV probit to examine the correlation between shocks and binary choices of adaptation strategies [55-58]

The dependent variables were four dummy variables: planting time, early maturing, drought resistant and farming methods equal to one, if the farmer household adopts the adaptation strategy decision, and zero if otherwise. The identified main adaptation strategies and their summary statistics are presented in Table 3.

$Y_{i k}^{*}=\beta_{k} X_{i k}+\alpha_{k} A_{i k}+\varepsilon_{k}$

where $(k=1, \ldots \ldots, m)$

$Y_{i k}=1 i f Y_{i k}^{*}>0$ and Ootherwise

where $Y_{i k^{\prime}}^{*}$ a latent variable which captures the unobserved and the observed choices is associated with $k^{\text {th }}$ climate change adaptation strategies and $Y_{i k}$ represents the binary dependent variables, $(k=1, \ldots, m)$ denoting the different adaptation strategies used by the farmer households. $X_{i k}$ is the vector of the explanatory variables which represents the observed household and farm-specific characteristics, as well as institutional variables [59]. $A_{i k}$ represents household heads susceptibility to climate change such as awareness of climate change to account for the unobserved heterogeneity. $\beta_{k}$ and $\alpha_{k}$ are the conformable vectors to be estimated. From Eq. (4), $\left(\varepsilon_{k}\right)$ is the positive correlation between the error terms of adaptation strategies showing

Table 3 Summaries of adaptation strategies adopted by the farmer households in the BVB

\begin{tabular}{llll}
\hline S/no & Adaptation strategies & Yes (\%) & No (\%) \\
\hline 1 & Planting time & 52.33 & 47.67 \\
2 & Early maturing crops & 63.33 & 36.67 \\
3 & Drought-resistant crops & 61.83 & 38.17 \\
4 & Mulching & 26 & 74 \\
5 & Irrigation & 3.5 & 96.5 \\
6 & Farming methods & 73.5 & 26.5 \\
\hline
\end{tabular}

the complementarity between strategies, while negative correlations show substitutability. The error term, $\varepsilon_{k}$ have multivariate normal distributions with zero conditional averages, unitary variance, and an $n \times n$ correlation matrix [60]: where $\varepsilon_{k} \approx \operatorname{MVN}(0, \phi)$ and the covariance matrix $\phi$ is expressed as:

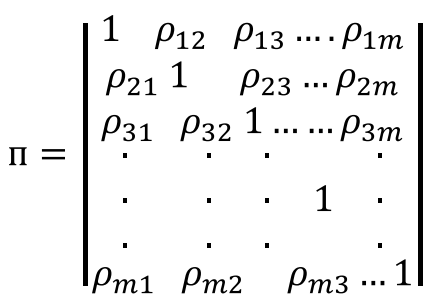

where $\rho$ denotes the correlation that is unobserved between the stochastic elements of the error terms in relation to any two adoption equations to be computed in the model. In Eq. (5), the correlation between the stochastic elements of the various adaptation strategies adopted by a farmer household is denoted by the offdiagonal components (for instance, $\rho_{21}, \rho_{12}, \rho_{31}$, and $\rho_{13}$ ) in the variance-covariance matrix [61]. The assumption of the unobserved correlation between the stochastic element of the $k$ th and $m$ th forms of adaptation strategies reveals that Eq. (4) gives a multivariate model that jointly signifies decisions to adopt a specific adaptation strategy. The specification with nonzero off-diagonal components enables for correlation across the error terms of several latent equations, which represent unobserved features that affect preferences of alternative adaptation strategies.

\subsection{Dependent variables MV probit model}

The adaptation strategies that farmer households adopted to mitigate the implications of climate change include planting time, early maturing, drought resistant, mulching, irrigation and farming methods. Stata software was used for the data analysis for this model.

These adaptation strategies can be employed to modify the span of the planting season-for example-by employing water conservation techniques. Resource insufficiencies coupled with household characteristics and limited infrastructure inhibits the ability of most farmers to take up adaptation strategies in response to climate change [25]. Table 3 presents summaries of adaptation strategies used by farmer households in the BVB. In all, six adaptation strategies were identified by farmer 
Table 4 Respondents socio-economic characteristics and response to climate change adaptation strategies for the binary logistic model

\begin{tabular}{|c|c|c|c|c|c|c|c|c|}
\hline Variable & Specification & Min & Max & Mean & SD & Freq & Per cent & $N$ \\
\hline Farmer adapts early planting time & yes $=1$, no $=0$ & & & & & 286 & 48 & 600 \\
\hline Farmer adapts early maturing crops & yes $=1$, no $=0$ & & & & & 220 & 37 & 600 \\
\hline Farmer adapts drought-resistant crops & yes $=1$, no $=0$ & & & & & 229 & 38 & 600 \\
\hline Farmer changes planting method & yes, no $=0$ & & & & & 160 & 27 & 600 \\
\hline Gender & Male $=1 ;$ female $=0$ & & & & & 528 & 88 & 600 \\
\hline Number of household size & Number in household & 1 & 3 & 1.49 & 0.58 & & & 600 \\
\hline FBO member & yes $=1$, no $=0$ & & & & & 462 & 77 & 600 \\
\hline Farmer aware of CC & yes $=1$, no $=0$ & & & & & 588 & 98 & 600 \\
\hline Age (yrs) & $25-45=1 ; 45-69=2$ & & & & & & & 600 \\
\hline Farm income (GHC) & $40-60=1 ; 61-1500=2$ & & & & & & & 596 \\
\hline Education (yrs) & $0-15=1 ; 16-20=2$ & & & & & 547 & 92 & 593 \\
\hline Farm size (acres) & $2-15=1 ; 16-20=2$ & & & & & 492 & 83 & 594 \\
\hline District of respondent & $\begin{array}{l}\text { Nandom-Lawra }=1 ; \text { Lambussie-Karni }=2 ; \text { Nadowli- } \\
\text { Kaleo }=3 ; \text { Jirapa }=4 ; \text { Wa Municipal = 5; Wa west }=6 ; \\
\text { Wa East }=7\end{array}$ & & & & & & & 600 \\
\hline
\end{tabular}

Note: FBO is farmer-based organization/group, CC is climate change, GHC is Ghana Cedis (exchange rate in December 2018, US\$1=GHC4.8)

households; however, four were significant for empirical estimation.

\subsection{Explanatory variables for MV Probit model}

These variables comprised socio-demographic characteristics such as age, gender, year of education, household size, farm income, farm size, FBO membership and climate change awareness. The age of a farmer informs his/her exposure to varying farming experiences, systems, and seasons. Thus, it is likely that the age of a farmer will positively impact his/her perception of climate change [62]. In this current study, age was hypothesized to have both negative and positive influences on the selection of adaptation strategies.

Many studies have revealed the importance of gender influencing the choice of climate change adaptation strategies at the farm level. Farmers who happen to be female are expected to adopt adaptation strategies and natural resource management [63-65]. However, the findings of [66] revealed that a farmer's gender was a statistically insignificant variable to inform a farmer's choice of an adaptation strategy.

Farming experience and education are significant factors informing the decision of a farmer on selecting an adaptation strategy. Many studies have revealed that enhancing education and disseminating knowledge is a relevant policy measure for motivating local involvement in natural resource management initiatives and various development $[63,67-69]$. It is projected that education will have positive influence on a farmer's decision to select an adaptation strategy.

Huge household size could support the discussion, harmonization and sharing of climate-related observations which could positively affect the awareness of farmers on climate change. A large household can solely rely on hired labour, which can lead to poor awareness of climate change. Thus, household size could negatively or positively affect the farmer's awareness of climate change [62]. Higher farm income could support the ability of a farmer to improve their experience and acquire bigger farm sizes. For instance, higher household income can enable the accessibility to relaxed liquidity constraints, i.e. improving the adoption of technology [70]. However, a low household income will result otherwise. Thus, it is likely that farm income will have both positive and negative influences on a farmer's decision to select an adaptation strategy.

A farmer's access to climate-change-awareness information from sources such as television, radio and newspaper could enhance awareness on climate change and vice versa. Better agriculture and climate information enable farmers select adaptation strategies that help them to adapt well with climate change conditions [71, 72]. Finally, farmer-based organization (FBO) membership can increase the knowledge of farmers concerning climate change since diverse views on climate change experiences from various farmers will be shared. This could also improve the accessibility to extension contact resulting in raising their awareness of climate change [73]. Thus, it is likely that FBO membership will have both positive influences on a farmer's decision to select an adaptation strategy. 


\subsection{Binary logistic model}

A binary logistic model was also specified as a policy model [74] and used to model the farmer response to each of the four adaptation strategies namely, planting time, early maturing, drought resistant and change in farming methods. SPSS software was used for this data analysis for this model. As the dependent variable, each of them was equated to one, if the farmer adopts the adaptation strategy and zero, if otherwise (Table 4). The respondents' socio-economic characteristics are presented in Table 4. These were included in the binary logistic model as the explanatory variables. Initially, the correlation matrix for these variables indicated high correlation coefficients (Coeff $>0.7$ ) between the Nandom District (one location of the respondents), the lower classes of education, farm size, age and farm income variables and the remaining variables. To reduce these high correlation coefficients, the Nandom and Lawra Districts were collapsed into one, and the classes of the education, farm size, age and farm income variables were collapsed into two classes each. This produced the correlation matrix with coefficients $<0.4$ (SM Tables 1, 2, 3 and 4). Logistic regression with analysis of maximum likelihood estimates and odds ratio estimates as an alternative to the marginal effects were computed. Kruskal-Wallis Chi-square statistical test was carried out. This test was conducted for each of the four adaption strategies variable and the district of the respondents' variable. The purpose was to check if the responses of farmers in the 8 study districts to the 4 four adaption strategies were significantly different or not. The result for this test for changing planting time, planting early maturing crops, planting drought-resistant crops and change of planting methods adaptation strategies variable was significant $\left(X^{2}=44, d f=6, p\right.$-value $<0.0001 ; X^{2}=21, d f=6$, $p$-value $=0.002 ; X^{2}=32, d f=6, p$-value $=0.0001 ; X^{2}=23$, $d f=6, p$-value $=0.001$; respectively). This shows the differences in responses to the adaption strategies among the respondents in the study districts. The district of the respondent was included in the logistic regression as one of the explanatory variables. The pool data modelling was then ruled out because the dependent variables for this study were from a one-time cross-sectional data and not longitudinal or time series; as such, the Hausman's test does not also apply in this case.

\subsubsection{Results and discussion}

Table 5 presents the summary statistics of the variables for the MV probit model. The mean age and years of education of the household heads were 45 years and four years, respectively. This shows that majority (92\%) of sampled household heads were middle-aged and educated and hence have some knowledge of climate change and its risks. Several studies showed that level of education and age are critical socio-demographic determinants and proxy measures of social identity that scales household's or communities' coping capacity $[35,75-80]$. In terms of decision-making, power dynamics and negotiation within the household in a related study by [78] in the Upper West region of Ghana concurred that age and years of education had significant effect. Educated farmers are in better position to comprehend climate change and its associated risks. Moreover, education promotes knowledge acquisition and reasoning ability of farmers about modern technologies thereby influencing them to adopt. Approximately $84 \%$ of the households were headed by males. This is in line with the findings of [14] and [60] where $81.94 \%$ and $83 \%$ of the majority were males, respectively. Findings from $[81,82]$ have shown that more male-headed household are adapted to climate change strategies than female-headed household. Contrarily, a study [55] in the Nile Basin of Ethiopia found more female-headed households highly probable to adopt climate change adaptation methods. This study suggests that females are marginalized due to the patrilineal system of inheritance and succession which affected their ability to adapt to climate change. Customarily, men enjoy favouritism in their male-controlled roles and advocated structural disparities among women in terms of taking sides on decision regarding access to and control over land for agricultural activities and the ability to engage in more productive activities compared to their male counterparts [83, 84]. The crucial role of women in climate change adaptation cannot be side-stepped, specifically because women are key agents of change. Thus, their knowledge can provide stimuli towards adaptive mechanisms in most vulnerable areas $[85,86]$.

Studies from [87] found out that issue of the environment matters most to women than men. This signifies that females prioritize and uphold the true value of the environment than males, a sign that women may subscribe more to mitigation strategies than adaptation strategies. Access to land is significant and crucial to adaption in the study area as it is linked to livelihoods, vulnerability and social status of the people. Nonetheless, it is not only the access that is important though, control over resources, such as land titling and tenure rights are likewise significant issues. The reasoning is that if women were to have the same access to and control over resources as men, this would provide increased possibilities for food production by women [88]; findings in Upper East region of Ghana found that women were marginalized in terms of land ownership and property possession or allocation hence treated as foreigners and have no bearing to any ancestral heritage. 


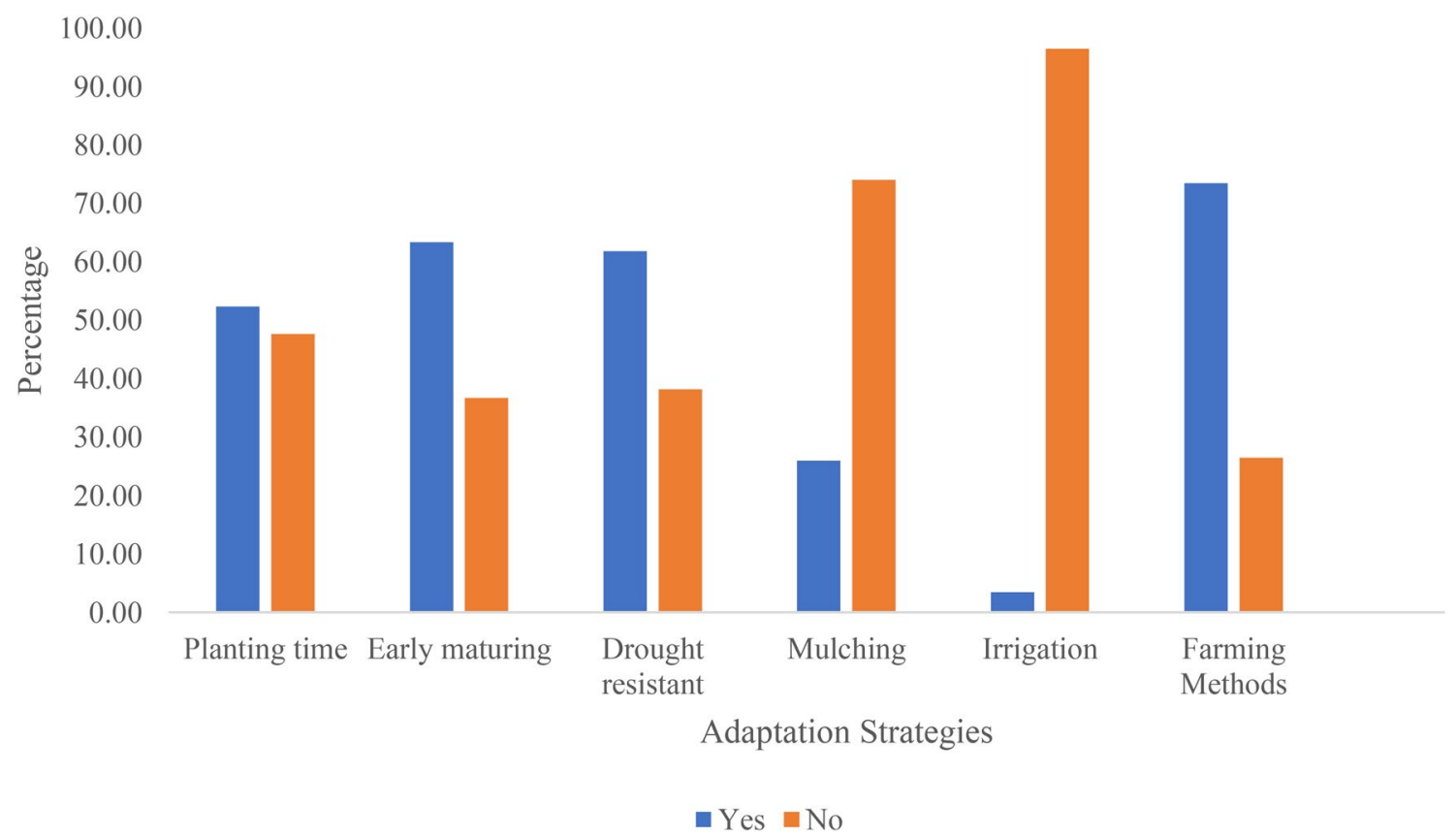

Fig. 2 Summaries of the choice of adaptation strategies to climate change in BVB

Results of the study also revealed a positive relationship between membership to farmer-based organization (FBOs) and adaptation to climatic change. Approximately $34 \%$ of the households are members of FBO. With this low level of membership, farmers should be motivated to join and actively engage in FBOs. There is little chance for a farmer-based organization (FBO)-affiliated member to be predisposed to climatic stressors. Several motivational packages and assistance from Non-Governmental Organization (NGO's) and philanthropic agents constitute a good step towards building resilient capacities. Actively engaged FBO farmers will have the potential of spearheading their access to information towards climate change adaptability than a non-FBO member. FBO affiliation gives the grounds for farmers to disseminate ideas or information particularly regarding adaptation strategies. In this way, farmers are also able to impact one another in learning from other experienced farmers in technical aid, enhancing access to credit and facilitating access to weather information from such associations leading to increased adoption of strategies. This is consistent with earlier research findings in Nepal and Bangladesh that showed that farmers belonging to cooperative organizations have higher likelihood of using adaptation practices due to their capacity to share information-discuss problems, share ideas and take collaborative decisions $[89,90]$. However, another study [91] in Vietnam found that membership in organizations did not necessarily influence farm household's use of climate adaptation strategies. This low drift in FBO member subscription in the study area could be attributable to the fact that FBOs are inclining to market integration (good prices and bonuses) and other social incentives that merits them.

At the local level, awareness of climate change is a crucial step towards guaranteeing fruitful response to adaptation. From the results, majority of the household heads were aware of changes in inherent climate change and related adaptation strategies. This observational outlook concurred with [80] whose report showed that almost all households in agro-ecological zones of Uganda had experienced climate change, while $[92,93]$ and [94] found that farmers in the Nile Basin of Ethiopia, Kenya and Ghana, respectively, showed high level of awareness of climate change. [95] study report indicated $89.8 \%$ level of climate change awareness in Nigeria, while [96] reported high awareness level in climate change drawing from an experimental analytical studies done in Africa. Regardless of the educational status one has attained, indigenous indicators such as seasonal variations in rainfall has been used as observational trend check in climate change when they (indigenes) were young and growing up. Rainfall has been emphasized as major hydro-climatic driver in several communities in Northern Ghana [97-99]. With deep understanding of local environmental conditions, crucial evidences on their livelihood and landmarks in their farms and communities are used to support affirmations that truly rainfall has reduced [100]. A better understanding of the local dimensions of climatic change is also crucial to come up with the opposite adaptation measures that can mitigate the adverse impact of climate 
Table 5 Descriptive statistics of variables for the MV probit model

\begin{tabular}{|c|c|c|c|}
\hline Variable & Description of variable & Mean & Std Dev \\
\hline \multicolumn{4}{|l|}{ Dependent } \\
\hline Planting time & $\begin{array}{l}\text { Dummy }=1 \text { if farmer household adapted early planting time as an adaptation strategy, } 0 \\
\text { otherwise }\end{array}$ & 0.48 & 0.51 \\
\hline Early Maturing & $\begin{array}{l}\text { Dummy }=1 \text { if farmer household adapted early maturing crops as an adaptation strategy, } \\
0 \text { otherwise }\end{array}$ & 0.37 & 0.48 \\
\hline Drought resistant & $\begin{array}{l}\text { Dummy }=1 \text { if farmer household adapted drought-resistant varieties as an adaptation } \\
\text { strategy, } 0 \text { otherwise }\end{array}$ & 0.38 & 0.49 \\
\hline Mulching & Dummy $=1$ if farmer household adapted mulching as an adaptation strategy, 0 otherwise & 0.26 & 0.44 \\
\hline Irrigation & Dummy $=1$ if farmer household adapted irrigation as an adaptation strategy, 0 otherwise & 0.04 & 0.18 \\
\hline Farming methods & $\begin{array}{l}\text { Dummy }=1 \text { if household adapted changing farm methods as an adaptation strategy, } 0 \\
\text { otherwise }\end{array}$ & 0.27 & 0.48 \\
\hline \multicolumn{4}{|l|}{ Explanatory variable } \\
\hline Age & Age of household head in years & 45.79 & 7.51 \\
\hline Gender & Gender of household head, $1=$ male, 0 otherwise & 0.84 & 0.18 \\
\hline Education & Years of education of the household head & 4.22 & 2.51 \\
\hline Household size & Number of household size & 8.12 & 2.57 \\
\hline FBO & Dummy $=1$ if household head or spouse are members of farmer group, 0 otherwise & 0.34 & 0.21 \\
\hline Income & Farm income of household in Ghana Cedis & 1984.12 & 297.11 \\
\hline Farm size & Size of a farm owned by the household in acres & 8.12 & 2.57 \\
\hline Climate change awareness & Dummy $=1$ if farmer is aware of climate change, 0 otherwise & 0.82 & 0.14 \\
\hline
\end{tabular}

Source: Authors' construction, 2018

Table 6 Correlation matrix of the adaptation strategies constraint from the MV probit model

\begin{tabular}{|c|c|c|c|c|}
\hline & Planting time & Early maturing & Drought-resistant & $\begin{array}{l}\text { Farming } \\
\text { methods }\end{array}$ \\
\hline \multicolumn{5}{|l|}{ Planting time } \\
\hline Early maturing & $0.337(0.095)^{*}$ & & & \\
\hline Drought resistant & $0.239(0.071)^{*}$ & $0.885(0.047)^{*}$ & & \\
\hline Farming methods & $0.848(0.042)^{* *}$ & $0.468(0.112)$ & $0.765(0.081)^{*}$ & \\
\hline Likelihood ratio test $\left(\mathrm{Chi}^{2}\right)$ & $\mathrm{Chi}^{2}(4)=$ & 288.606 & & \\
\hline$P$-value & 0.000 & & & \\
\hline Joint probability (success) & 42.213 & & & \\
\hline Joint probability (failure) & 19.235 & & & \\
\hline \multicolumn{5}{|l|}{ Linear predictions } \\
\hline Planting time & 0.697 & & & \\
\hline Early maturing & 0.621 & & & \\
\hline Drought resistant & 0.644 & & & \\
\hline Farming methods & 0.687 & & & \\
\hline
\end{tabular}

change ultimately improving rural livelihoods and reducing vulnerability [80-85]. For several years, this indigenous knowledge application has been given due observation locally as form of awareness creation such that if a farmer is oblivious to render such practices, others would have been seen put into practice and some instances through conversations with others. This finding concurred with [101] who assessed the extent of community observation of changes in climate and associated impacts as well as community-based approaches used in coping with the changes in the northern and coastal Savannah ecological zones of Ghana. 


\subsection{Correlation matrix of choice of adaptation strategies to climate change}

Farmer households who participated in the study were asked to identify the factors influencing farmers' choice of adaptation strategies. Figure 2 presents summaries of the results. Four major factors identified were changing planting time, planting early maturing crops, planting droughtresistant crops, and changing farm methods. These factors are paramount for adopting adaptation strategies. To establish the factors that influence the adoption of adaptation strategies among the household heads in the study area, the four identified factors to the adoption of climate change strategies served as the outcome variables in the $M V$ probit model. The correlation matrix results from the MV probit model are presented in Table 5.

The likelihood ratio test $\mathrm{Chi}^{2}(4)=288.606, p>0.000$ ) of the independence of the error term of the different adaptation equations is rejected (see Table 6). Thus, the study accepted the alternative hypothesis of the mutual interdependence among the multiple adaptation strategies. Hence, the results of the study support the application of the MV probit model. Also, all the pairwise coefficients showed a positive correlation signifying complementarity among these adaptation strategies. The results show that the joint probability of adopting the preferred adaptation strategies was $42 \%$, whereas not adopting the preferred adaptation was $19 \%$. The linear prediction of the results reveals that the likelihood of adopting changing planting time, planting early maturing crops, planting droughtresistant crops and changing farming methods is $70 \%$, $62 \%, 64 \%$ and $69 \%$, respectively.

\subsection{MV probit parameter estimates of choice of adaptation strategies to climate change}

\subsubsection{Changing planting time}

Several studies [102-104] have firmly grounded the assertion that changing planting time is the most preferred climate change adaptation strategy employed by farmers. The positive coefficient for gender indicates that maleheaded households are more likely to change planting time (see Table 7). This could be due to the dominance of household heads who are males. This is consistent with $[75,102]$ who found that male farmers had higher likelihood of adopting climate adaptation strategies than their female counterparts. Contrarily, [105] evaluated that females have high likelihood of changing their plantings as a result of their high vulnerability to climate change, as a matter of necessity needed to execute some actions. However, planting time was negatively affected by household and farm sizes. This is in line with the findings of [65] who noted that changing planting time is an autonomous decision that can be taken by the household head and may not require more labour. The negative coefficients of household size and farm size indicate that small households with small farm sizes are likely to change planting time. The negative coefficient for age indicates that young household heads are likely to change planting time compared to the older heads possibly for their innovative nature and their quest to try new strategies to enhance agriculture. This is in agreement with the findings of [106] who found that, despite the older farmers being aware of current innovations, they are reluctant to try new strategies. Finally, changing planting time is positively affected by the awareness of climate change indicating that household heads who are aware of climate change are likely to change planting time in BVB areas. The farmers using indigenous knowledge over the years have enhanced their understanding on the information regarding planting
Table 7 MV probit model estimates for factors influencing the adoption of adaptation strategies

\begin{tabular}{lllll}
\hline & Planting time & Early maturing & Drought resistant & Farming methods \\
\hline Variable & Coef (std error) & Coef (std error) & Coef (std error) & Coef (std error) \\
Gender & $0.293(0.167)^{*}$ & $-0.096(0.174)$ & $0.244(0.171)^{*}$ & $-0.043(0.175)$ \\
Age & $-0.011(0.007)^{*}$ & $0.005(0.007)$ & $0.001(0.007)$ & $-0.013(0.008)^{*}$ \\
Household size & $-0.134(0.142)^{*}$ & $-0.121(0.098)$ & $0.023(0.094)$ & $-0.063(0.102)$ \\
FBO membership & $-0.055(0.128)$ & $-0.094(0.132)$ & $0.254(0.428)^{*}$ & $-0.097(0.136)$ \\
Farm income & $0.112(0.121)^{*}$ & $0.005(0.007)^{* * *}$ & $0(0.001)$ & $0(0.001)$ \\
Years of education & $-0.01(0.009)$ & $-0.003(0.009)$ & $0.005(0.009)^{* *}$ & $0.009(0.01)$ \\
Farm size & $-0.014(0.011)^{*}$ & $-0.011(0.011)$ & $0.005(0.011)$ & $-0.022(0.012)^{*}$ \\
Climate change Awareness & $0.337(0.400)^{* *}$ & $-0.084(0.395)$ & $0.184(0.391)$ & $0.815(0.384)^{* *}$ \\
Constant & $0.61(0.575)$ & $-0.104(0.586)$ & $-0.953(0.563)^{*}$ & $1.305(0.581)^{* *}$ \\
\hline
\end{tabular}

${ }^{*},{ }^{* *}$ and ${ }^{* * *}$ represent $10 \%, 5 \%$ and $1 \%$ significance level, respectively. FBO: farmer-based organization 
times especially planting at non-climatic times and are conversant with the dangers involved with planting early. Some farmers reported that there has been a continuous drastic decline in the performance of major crops spanning three decades. Farmers were of the view that meeting the raining season right at the onset and not following the usual farming period could enhance their preparedness and readily avail the essential inputs needed to sow. [107] in Ethiopia recognized that changing planting time and crop varieties was the most significant farming practice farmers used to abate the rigors of climate change in a similar lowland geographical setting. In the same study, a good knowledge about variability in rainfall and temperature enhanced the chances of changing planting date shifting by $39 \%$ and this development followed similar assertions from several studies $[42,55,92,108,109]$. This study is consonant with the findings of [39] and [40] who noted that the period of planting for crops in northern Ghana has changed from early April 1960s to late April or early May in recent times due to the unpredictable nature of precipitation and the changing environmental conditions, especially rainfall amounts and distribution.

In Table 8, the inferential goodness-of-fit test for the Hosmer-Lemeshow $(\mathrm{H}-\mathrm{L})$ test yielded a $X^{2}(8)$ of 7.053 and was insignificant $(p=0.531)$, suggesting that the model was fit to the data well. The Cox and Snell $R^{2}=0.089$ and Nagelkerke $R^{2}=0.119$. In Table 8, household heads in Wa
West $(p<0.0001)$ and East $(p=0.005)$, Wa Municipal ( $p<$ $0.0001)$, and Nadowli-Kaleo $(p<0.0001)$ are more likely to adopt change in planting time (early planting time) compared to their counterparts in the Nandom-Lawra District. In these districts, the elderly $(p=0.004)$ are less likely to adopt the early planting time compared to the younger household heads (Table 8). Findings from [110] revealed that Northern Ghana is recognized for poor rainfalls and high temperature, early planting could help farmers obtain good yield as well as reduce the impact of unfavourable climatic conditions.

\subsection{Planting early maturing crops}

Planting early maturing crops was positively affected by farm income. Farm income determines the purchasing power of a household head to purchase seeds of early maturing crops. Farm income can be maximized by increasing access to credit services and markets. This conforms to the findings of [111-113] and [13] who noted a positive effect of better access to credit services on the likelihood of a household adopting the cultivation of different crops as an adaptation strategy and neglecting the risk of sticking to mono-cropping systems relatively. [65] further found that expanding the accessibility of financial and other resources (such as markets) at the disposal of farmer households enables them to utilize all available

Table 8 Logistic regression estimates (maximum likelihood and odds ratios) for socio-economic data-predicting adaption of early planting time (1) versus none (0)

\begin{tabular}{|c|c|c|c|c|c|c|c|c|c|}
\hline \multirow[b]{2}{*}{ Parameter } & \multirow[b]{2}{*}{ B } & \multirow[b]{2}{*}{ SE } & \multicolumn{2}{|l|}{ Wald's } & \multirow[b]{2}{*}{$P$-value } & \multirow[b]{2}{*}{ Parameter } & \multirow[t]{2}{*}{ Odds ratio } & \multirow[t]{2}{*}{$95 \%$} & \multirow[t]{2}{*}{ Cl limit } \\
\hline & & & $x^{2}$ & df & & & & & \\
\hline Gender: man & 0.333 & 0.284 & 1.37 & 1 & 0.242 & vs woman & 1.395 & 0.799 & 2.434 \\
\hline \multicolumn{10}{|l|}{ Age group } \\
\hline $46-69$ & -0.539 & 0.188 & 8.204 & 1 & 0.004 & vs. $25-45$ & 0.584 & 0.404 & 0.844 \\
\hline Climate change awareness (yes) & -0.769 & 0.753 & 1.045 & 1 & 0.307 & vs. no & 0.463 & 0.106 & 2.025 \\
\hline FBO member (yes) & -0.195 & 0.227 & 0.739 & 1 & 0.390 & vs. no & 0.823 & 0.527 & 1.284 \\
\hline \multicolumn{10}{|l|}{ Educational level (years) } \\
\hline $16-20$ & 0.079 & 0.342 & 0.053 & 1 & 0.818 & vs. $0-15$ & 1.082 & 0.553 & 2.116 \\
\hline \multicolumn{10}{|l|}{ Farm size (acres) } \\
\hline $16-30$ & -0.016 & 0.259 & 0.004 & 1 & 0.950 & vs. $2-15$ & 0.984 & 0.593 & 1.634 \\
\hline Household size $(n)$ & 0.046 & 0.165 & 0.078 & 1 & 0.781 & & 1.047 & 0.758 & 1.446 \\
\hline \multicolumn{10}{|l|}{ Farm income (GHC/year) } \\
\hline $61-1500$ & 0.01 & 0.201 & 0.002 & 1 & 0.962 & vs. $40-60$ & 1.01 & 0.681 & 1.498 \\
\hline \multicolumn{10}{|l|}{ Respondent's location (District) } \\
\hline Lambussie-Karni & 0.612 & 0.323 & 3.581 & 1 & 0.058 & vs. Nandom-Lawra & 1.844 & 0.978 & 3.476 \\
\hline Nadowli-Kaleo & 1.167 & 0.314 & 13.767 & 1 & 0.000 & vs. Nandom-Lawra & 3.212 & 1.734 & 5.948 \\
\hline Jirapa & 0.037 & 0.333 & 0.013 & 1 & 0.910 & vs. Nandom-Lawra & 1.038 & 0.541 & 1.993 \\
\hline Wa Municipal & 1.099 & 0.312 & 12.378 & 1 & 0.000 & vs. Nandom-Lawra & 3.001 & 1.627 & 5.535 \\
\hline Wa West & 1.428 & 0.324 & 19.395 & 1 & 0.000 & vs. Nandom-Lawra & 4.171 & 2.209 & 7.874 \\
\hline Wa East & 0.847 & 0.303 & 7.819 & 1 & 0.005 & vs. Nandom-Lawra & 2.332 & 1.288 & 4.223 \\
\hline
\end{tabular}

The significant values ( $p$ values) have been provided for these bold values in the text 
Table 9 Logistic regression estimates (maximum likelihood and odds ratios) for socio-economic data-predicting adaption of early maturing crops ( 1 ) versus none (0)

\begin{tabular}{|c|c|c|c|c|c|c|c|c|c|}
\hline Parameter & B & SE & Wald's & df & $P$-value & Parameter & Odds ratio & $95 \%$ lower & $\mathrm{Cl}$ limit upper \\
\hline Gender: man & -0.27 & 0.281 & 0.907 & 1 & 0.341 & vs. woman & 0.765 & 0.441 & 1.327 \\
\hline \multicolumn{10}{|l|}{ Age group } \\
\hline $46-69$ & 0.001 & 0.189 & 0.000 & 1 & 0.994 & vs. $25-45$ & 1.001 & 0.691 & 1.451 \\
\hline Climate change awareness (yes) & 0.049 & 0.665 & 0.006 & 1 & 0.941 & vs. no & 1.051 & 0.285 & 3.872 \\
\hline FBO member (yes) & -0.11 & 0.226 & 0.218 & 1 & 0.641 & vs. no & 0.900 & 0.577 & 1.402 \\
\hline \multicolumn{10}{|l|}{ Educational level (years) } \\
\hline $16-20$ & 0.496 & 0.337 & 2.172 & 1 & 0.141 & vs. $0-15$ & 1.642 & 0.849 & 3.176 \\
\hline \multicolumn{10}{|l|}{ Farm size (acres) } \\
\hline $16-30$ & -0.42 & 0.275 & 2.325 & 1 & 0.127 & vs. $2-15$ & 0.657 & 0.383 & 1.127 \\
\hline Household size $(n)$ & -0.21 & 0.17 & 1.595 & 1 & 0.207 & & 0.807 & 0.579 & 1.126 \\
\hline \multicolumn{10}{|l|}{ Farm income (GHC/year) } \\
\hline $61-1500$ & 0.191 & 0.208 & 0.846 & 1 & 0.358 & vs. $40-60$ & 1.211 & 0.805 & 1.82 \\
\hline \multicolumn{10}{|l|}{ Respondent's location (district) } \\
\hline Lambussie-Karni & 0.871 & 0.33 & 6.951 & 1 & 0.008 & vs. Nandom-Lawra & 2.389 & 1.25 & 4.564 \\
\hline Nadowli-Kaleo & 0.714 & 0.315 & 5.133 & 1 & 0.023 & vs. Nandom-Lawra & 2.042 & 1.101 & 3.786 \\
\hline Jirapa & -0.12 & 0.358 & 0.111 & 1 & 0.739 & vs. Nandom-Lawra & 0.887 & 0.44 & 1.789 \\
\hline Wa Municipal & 1.007 & 0.315 & 10.252 & 1 & 0.001 & vs. Nandom-Lawra & 2.738 & 1.478 & 5.073 \\
\hline Wa West & 0.746 & 0.324 & 5.317 & 1 & 0.021 & vs. Nandom-Lawra & 2.109 & 1.118 & 3.976 \\
\hline Wa East & 0.465 & 0.313 & 2.207 & 1 & 0.137 & vs. Nandom-Lawra & 1.593 & 0.862 & 2.943 \\
\hline
\end{tabular}

The significant values ( $p$ values) have been provided for these bold values in the text

information to change their management practices in response to changing climatic conditions.

In Table 9, the inferential goodness-of-fit test for the Hosmer-Lemeshow $(\mathrm{H}-\mathrm{L})$ test yielded a $X^{2}(8)$ of 11.374 and was insignificant $(p=0.181)$, suggesting that the model was fit to the data well. The Cox and Snell $R^{2}=0.049$ and Nagelkerke $R^{2}=0.067$. Household heads in LambussieKarni $(p=0.008)$, Nadowli-Kaleo $(p=0.023)$, Wa West ( $p$ $=0.021)$, and Wa Municipal $(p=0.001)$ are more likely to adopt early maturing crops compared to those in the Nandom-Lawra District (Table 9). [75] revealed the critical need to mitigate the changing climate effect through the development of improved varieties such as early maturing crops necessary to sustain the productivity.

\subsection{Planting drought-resistant varieties}

Gender, FBO membership, and years of education had positive influence on planting drought-resistant varieties (see Table 10). The positive coefficient of gender indicates household heads who are males. This is in consonance with the findings of [65] who noted that the choices of crop varieties as an adaptation strategy are largely dictated by the gender of the household head. The study further revealed that male household heads are more likely to plant different crop varieties as an adaptation strategy. FBO membership had a positive impact on planting drought-resistant crops. FBO membership could lead to sharing experiences and information about current technologies when they meet [58]. [60] also noted that more kinship ties which act as a form of group dynamics have a positive impact on adopting drought-resistant crops as an adaptation strategy. Moreover, these ties facilitate the sharing of information and seeds in the form of gifts among others from one relative to another and lead to the massive spread of improved seeds and the fast adoption of technologies. Consistent with the findings of $[60,114]$ and $[115]$, the results revealed that household heads with more years of education have a high tendency of adopting droughtresistant crops. The educated household heads tend to be less risk-averse $[116,117]$, leading to a higher adoption rate among them. Studies $[78,118,119]$ advocated improved extension education to improve intensity of use of adaptation options.

The inferential goodness-of-fit test for the Hosmer-Lemeshow $(\mathrm{H}-\mathrm{L})$ test yielded a $X^{2}(8)$ of 7.30 and was insignificant $(p=0.505)$, suggesting that the model was fit to the data well. The Cox and Snell $R^{2}=0.063$ and Nagelkerke $R^{2}=0.086$ (Table 10). Farmers in Lambussie-Karni ( $p$ $=0.008)$, Wa West $(p=0.003)$, Wa East $(p=0.001)$ and Wa Municipal ( $p=0.009$ ) districts are more likely to adopt 
Table 10 Logistic regression estimates (maximum likelihood and odds ratios) for socio-economic data-predicting adoption of droughtresistant crop varieties ( 1 ) versus none (0)

\begin{tabular}{|c|c|c|c|c|c|c|c|c|c|}
\hline \multirow[t]{2}{*}{ Parameter } & \multirow[t]{2}{*}{ B } & \multirow[t]{2}{*}{ SE } & \multicolumn{2}{|l|}{ Wald's } & \multirow[t]{2}{*}{$P$-value } & \multirow[t]{2}{*}{ Parameter } & \multirow[t]{2}{*}{ Odds ratio } & \multicolumn{2}{|c|}{$95 \% \mathrm{Cl}$ limit } \\
\hline & & & $x^{2}$ & $d f$ & & & & Lower & Upper \\
\hline Gender: man & 0.381 & 0.298 & 1.637 & 1 & 0.201 & vs. woman & 1.464 & 0.817 & 2.624 \\
\hline \multicolumn{10}{|l|}{ Age group } \\
\hline $46-69$ & 0.03 & 0.189 & 0.025 & 1 & 0.874 & vs. $25-45$ & 1.031 & 0.711 & 1.494 \\
\hline Climate change awareness (yes) & 0.585 & 0.683 & 0.733 & 1 & 0.392 & vs. no & 1.795 & 0.471 & 6.843 \\
\hline FBO member (yes) & -0.1 & 0.228 & 0.19 & 1 & 0.663 & vs. no & 0.905 & 0.579 & 1.416 \\
\hline \multicolumn{10}{|l|}{ Educational level(yrs) } \\
\hline $16-20$ & 0.345 & 0.347 & 0.986 & 1 & 0.321 & vs. $0-15$ & 1.412 & 0.715 & 2.789 \\
\hline \multicolumn{10}{|l|}{ Farm size (acres) } \\
\hline $16-30$ & 0.424 & 0.264 & 2.585 & 1 & 0.108 & vs. $2-15$ & 1.528 & 0.911 & 2.561 \\
\hline Household size (n) & 0.014 & 0.167 & 0.007 & 1 & 0.932 & & 1.014 & 0.732 & 1.406 \\
\hline \multicolumn{10}{|l|}{ Farm income (GHC/yr) } \\
\hline $61-1500$ & -0.09 & 0.204 & 0.211 & 1 & 0.646 & vs. $40-60$ & 0.911 & 0.611 & 1.358 \\
\hline \multicolumn{10}{|l|}{ Respondent's location (district) } \\
\hline Lambussie-Karni & 0.873 & 0.331 & 6.976 & 1 & 0.008 & vs. Nandom-Lawra & 2.395 & 1.253 & 4.578 \\
\hline Nadowli-Kaleo & 0.536 & 0.322 & 2.771 & 1 & 0.096 & vs. Nandom-Lawra & 1.708 & 0.909 & 3.211 \\
\hline Jirapa & -0.48 & 0.364 & 1.7 & 1 & 0.192 & vs. Nandom-Lawra & 0.622 & 0.305 & 1.27 \\
\hline Wa Municipal & 0.816 & 0.314 & 6.759 & 1 & 0.009 & vs. Nandom-Lawra & 2.261 & 1.222 & 4.181 \\
\hline Wa West & 0.947 & 0.321 & 8.734 & 1 & 0.003 & vs. Nandom-Lawra & 2.579 & 1.376 & 4.833 \\
\hline Wa East & 1.040 & 0.308 & 11.404 & 1 & 0.001 & vs. Nandom-Lawra & 2.829 & 1.547 & 5.173 \\
\hline
\end{tabular}

The significant values ( $p$ values) have been provided for these bold values in the text

Table 11 Logistic regression estimates (maximum likelihood and odds ratios) for socio-economic data-predicting adaption of change in farming methods ( 1 ) versus none (0)

\begin{tabular}{|c|c|c|c|c|c|c|c|c|c|}
\hline \multirow[t]{2}{*}{ Parameter } & \multirow[t]{2}{*}{ B } & \multirow[t]{2}{*}{$\mathrm{E}$} & \multicolumn{3}{|c|}{$\begin{array}{l}\text { Wald's } \\
P\end{array}$} & \multirow[t]{2}{*}{ Parameter } & \multirow[t]{2}{*}{ Odds ratio } & \multirow{2}{*}{$\begin{array}{l}\text { 95\% } \\
\text { Lower }\end{array}$} & \multirow{2}{*}{$\begin{array}{l}\text { CI limit } \\
\text { Upper }\end{array}$} \\
\hline & & & $\overline{x^{2}}$ & $d f$ & & & & & \\
\hline Gender: man & 0.095 & 0.308 & 0.094 & 1 & 0.759 & vs woman & 1.099 & 0.601 & 2.012 \\
\hline \multicolumn{10}{|l|}{ Age group } \\
\hline $46-69$ & -0.49 & 0.206 & 5.616 & 1 & 0.018 & vs. $25-45$ & 0.614 & 0.41 & 0.919 \\
\hline Climate change awareness (yes) & -1.10 & 0.666 & 2.716 & 1 & 0.099 & vs. no & 0.333 & 0.09 & 1.231 \\
\hline FBO member (yes) & -0.36 & 0.242 & 2.233 & 1 & 0.135 & vs. no & 0.696 & 0.433 & 1.119 \\
\hline \multicolumn{10}{|l|}{ Educational level (years) } \\
\hline $16-20$ & 0.261 & 0.351 & 0.553 & 1 & 0.457 & vs. $0-15$ & 1.298 & 0.653 & 2.581 \\
\hline \multicolumn{10}{|l|}{ Farm size (acres) } \\
\hline $16-30$ & -0.60 & 0.331 & 3.324 & 1 & 0.068 & vs. $2-15$ & 0.547 & 0.286 & 1.046 \\
\hline Household size $(n)$ & -0.08 & 0.186 & 0.197 & 1 & 0.657 & & 0.921 & 0.64 & 1.325 \\
\hline \multicolumn{10}{|l|}{ Farm income (GHC/year) } \\
\hline $61-1500$ & -0.15 & 0.226 & 0.463 & 1 & 0.496 & vs. $40-60$ & 0.858 & 0.551 & 1.335 \\
\hline \multicolumn{10}{|l|}{ Respondent's location (district) } \\
\hline Lambussie-Karni & 0.442 & 0.342 & 1.675 & 1 & 0.196 & vs. Nandom-Lawra & 1.556 & 0.797 & 3.04 \\
\hline Nadowli-Kaleo & -0.04 & 0.341 & 0.013 & 1 & 0.908 & vs. Nandom-Lawra & 0.961 & 0.492 & 1.877 \\
\hline Jirapa & -1.21 & 0.479 & 6.33 & 1 & 0.012 & vs. Nandom-Lawra & 0.299 & 0.117 & 0.766 \\
\hline Wa Municipal & -0.17 & 0.346 & 0.232 & 1 & 0.63 & vs. Nandom-Lawra & 0.846 & 0.429 & 1.668 \\
\hline Wa West & 0.034 & 0.345 & 0.01 & 1 & 0.921 & vs. Nandom-Lawra & 1.035 & 0.526 & 2.035 \\
\hline Wa East & 0.085 & 0.33 & 0.067 & 1 & 0.796 & vs. Nandom-Lawra & 1.089 & 0.571 & 2.078 \\
\hline
\end{tabular}

The significant values ( $p$ values) have been provided for these bold values in the text 
drought-resistant crop varieties compared to those in the Nandom-Lawra District (Table 10).

\subsection{Changing farming methods}

The results (Table 11) indicate a negative effect of age on changing farming methods as an adaptation strategy. This shows that young household heads $(p=0.018)$ are more likely to change farming methods compared to the older household heads. Similarly, the findings of [117] revealed the adoption of pesticides to be negatively affected by age as the young farmers were found to adopt pesticides as a new adaptation strategy, whereas the old farmers were reluctant. Household heads with small farm sizes $(p=0.068)$ are more likely but weakly to change farming methods as revealed by the results (Table 11). Changing farming methods on large farms may be capital intensive which may result in the failure of farmers meeting the cost of adaptation.

The inferential goodness-of-fit test for the Hosmer-Lemeshow $(\mathrm{H}-\mathrm{L})$ test yielded a $X^{2}(8)$ of 5.656 and was insignificant $(p=0.686)$, suggesting that the model was fit to the data well. The Cox and Snell $R^{2}=0.064$ and Nagelkerke $R^{2}=0.093$ (Table 11). Farm households in the Jirapa District ( $p=0.012$ ) are less likely to adopt change in farming methods compared to the farmers in the Nandom-Lawra District. For these farmers in the Jirapa District, the elderly are less likely to adopt change in the farming methods compared to the younger farmers (Table 11).

\section{Conclusions and recommendations}

\subsection{Conclusion}

The study focused on assessing the factors that influence climate change adaptation strategies in northern Ghana. The results of the study reveal that majority of the farmer households in the study area are aware of climate change and do adopt various adaptation strategies in their effort to adapt to the adverse effects of climate change. Significant adaptation strategies identified by the farmer households in response to the adverse effects of climate change include changing planting time, planting early maturing crops, planting drought-resistant varieties and changing farming methods.

Strong evidence was revealed that adoption choice of various adaptation strategies is interdependent due to the complementarity or substitutability between the adaptation strategies. Male household heads are more likely to change planting time, and households with smaller farm sizes and awareness of climate change will select this strategy. Adversely, changing planting time was negatively affected by age. Moreover, gender positively affected the adoption of drought-resistant varieties. Nonetheless, household heads with many years of education and who are FBO members are likely to adopt droughtresistant varieties. Planting early maturing crops was positively affected by household income. Age negatively affected changing planting time and farming methods. However, households with small farm sizes and who are aware of climate change will select this strategy. In summary, gender, age, household size, FBO membership, farm income, years of education, farm size and climate change awareness are significant in households' choice of climate change adaptation strategies. Farm household heads in the Wa West, Wa Municipal, Nadowli-Kaleo and LambussieKarni districts are more likely to adopt early planting time, early maturing crops and drought-resistant crop varieties than those in the Nandom and Lawra districts. Further, the elderly farmers in the Jirapa District are less likely to adopt change in the farming methods than those in the Nandom and Lawra districts.

\subsection{Recommendations}

As part of the top development agenda, priority should be given by the Government to empower efforts on improving household heads' adaptive capacity. Non-governmental and governmental organizations should invest in climate-resilient programmes. Formulating policies that focus on addressing the constraints to adaptation for smallholder farming systems have a massive potential to enhance household heads' adaptation to climate change. Moreover, programmes aimed at sensitizing household heads on climate change adaptation strategies-such as changing planting time, changing farm methods, planting early maturing, and planting drought-resistant varieties-through pieces of trainings and workshops must be encouraged by the Government. This can also be done through governmental support for research and the spread of suitable technologies to enable farmers adapt to climate change. Increasing crop diversification through the adoption of early maturing and drought-resistant crops to prevailing rainfall and temperature extremes can serve as a relevant form of climate insurance against temperature and rainfall variability in the BVB area. Non-governmental organizations that support agricultural activities by training farmers on using climate-smart methods may target these districts using the findings identified from this research work. Extension officers from the Ministry of Food and Agriculture (MoFA) may also employ findings from this research to assist farmers in their respective working areas to improve upon crop yield by adapting to climate friendly adaptation options. 


\section{Declarations}

Conflict of interest The authors declare that they have no competing interests.

Open Access This article is licensed under a Creative Commons Attribution 4.0 International License, which permits use, sharing, adaptation, distribution and reproduction in any medium or format, as long as you give appropriate credit to the original author(s) and the source, provide a link to the Creative Commons licence, and indicate if changes were made. The images or other third party material in this article are included in the article's Creative Commons licence, unless indicated otherwise in a credit line to the material. If material is not included in the article's Creative Commons licence and your intended use is not permitted by statutory regulation or exceeds the permitted use, you will need to obtain permission directly from the copyright holder. To view a copy of this licence, visit http://creativecommons. org/licenses/by/4.0/.

\section{References}

1. Niang I., Ruppel O.C, Abdrabo M.A., Essel, A, Lennard, C., Padgham, J., Urquhart, P. Africa. In: Barros VR, Field CB, Dokken DJ, Mastrandrea MD, Mach KJ, Bilir TE, Chatterjee M, Ebi KL, Estrada YO, Genova RC, Girma B, Kissel ES, Levy AN, MacCracken S, Mastrandrea PR, White LL (eds) (2014) Climate change: impacts, adaptation, and vulnerability. Part B: regional aspects. Contribution of Working Group II to the Fifth Assessment Report of the Intergovernmental Panel on Climate Change. Cambridge University Press, Cambridge, pp 1199-265

2. Anderson S, Morton J, Toulmin C (2010) Climate change for agrarian societies in drylands: implications and future pathways. In: Mearns R, Norton A (eds) Social dimensions of climate change: equity and vulnerability in a warming world. World Bank Publications, pp 199-230

3. Intergovernmental Panel on Climate Change (IPCC) (2014) Climate Change 2014: Impacts, adaptation and vulnerability: Contribution of Working Group II to the IPCC Fifth Assessment Report. Cambridge University Press, Cambridge

4. Schlenker W, Lobell DB (2010) Robust negative impacts of climate change on African agriculture. Environ Res Lett 5(1):014010

5. Trenberth KE, Fasullo JT, Shepherd TG (2015) Attribution of climate extreme events. Nat Clim Change 5(8):725-730

6. Antwi-Agyei P, Fraser ED, Dougill AJ, Stringer LC, Simelton E (2012) Mapping the vulnerability of crop production to drought in Ghana using rainfall, yield, and socioeconomic data. Appl Geogr 32(2):324-334

7. UNFCCC (2007) Report on the African Regional Workshop on Adaptation. FCCC/SBI/2007/2. UN Office at Geneva, Switzerland. 2007. Available online: http://unfccc.int/resource/docs/ 2007/sbi/eng/02.pdf (Accessed on September 5, 2020).

8. UNFCCC (2007) Report on the Workshop on Climate-Related Risks and Extreme Events. Note by the Secretariat. FCCC/ SBSTA/2007/7. UNFCCC. Bonn, Germany. 2007. Available online: http://unfccc.int/resource/docs/2007/sbsta/eng/07. pdf (Accessed on September 5, 2020).

9. Mabe FN, Sienso G, Donkoh SA (2014) Determinants of choice of climate change adaptation strategies in northern Ghana.

10. Boyd E, Cornforth RJ, Lamb PJ, Tarhule A, Lélé MI, Brouder A (2013) Building resilience to face recurring environmental crises in African Sahel. Nat Clim Chang 3(7):631-637

11. Thomas DS, Twyman C, Osbahr H, Hewitson B (2007) Adaptation to climate change and variability: farmer responses to intra-seasonal precipitation trends in South Africa. Clim Change 83(3):301-322

12. Sissoko $K$, van Keulen $H$, Verhagen J, Tekken V, Battaglini $A$ (2011) Agriculture, livelihoods, and climate change in the West African Sahel. Reg Environ Change 11(1):119-125

13. World Bank (2010) Economics of Adaptation to Climate Change. Ghana Country Study; World Bank: Washington, DC, USA

14. Mabe FN, Sarpong DB, Osei-Asare Y (2012) Adaptive capacities of farmers to climate change adaptation strategies and their effects on rice production in the Northern Region of Ghana. Russ J Agric Socio-Econ Sci 1(11):9-17

15. Boyd E, Cornforth RJ, Lamb PJ, Tarhule A, Lélé MI, Brouder A (2013) Building resilience to face recurring environmental crises in African Sahel. Nat Clim Change 3(7):631-637

16. Hassan R, Nhemachena C (2008) Determinants of African farmers' strategies for adapting to climatic change: multinomial choice analysis. Af J Agric Resource Econ 2(1):83-104

17. Dasgupta A, Baschieri A (2012) Vulnerability to climate change in rural Ghana: mainstreaming climate change in povertyreduction strategies. J Int Dev 22:803-820

18. Biesbroek GR, Klostermann JE, Termeer CJ, Kabat P (2013) On the nature of barriers to climate change adaptation. Reg Environ Change 13(5):1119-1129

19. Barry S, Wandel J (2005) Adaptation, adaptive capacity, and vulnerability. Global Environ Change, Elsevier Ltd

20. Annor FO (2012) Diagnostic study of the Black Volta Basin in Ghana. In-Service Training Centre, Upper West Region- Ghana

21. Dasgupta A, Baschieri A (2010) Vulnerability to climate change in rural Ghana: mainstreaming climate change in povertyreduction strategies. J Int Dev 22(6):803-820

22. Kassie M, Jaleta M, Shiferaw B, Mmbando F, Mekuria M (2013) Adoption of interrelated sustainable agricultural practices in smallholder systems: evidence from rural Tanzania. Technol Forecasting Soc Change 80(3):525-540

23. Aemro T, Mengistu K, Beyene T (2012) Climate change adaptation strategies of smallholder farmers: the case of Babile District, East Hararghe Zone of Oromiya Regional State of Ethiopia. J Econ Sustain Dev 3(14). ISSN 2222-1700 (Paper) ISSN 2222-2855.

24. Kurukulasuriya $P$, Mendelson $R$ (2006) Crop selection: adapting to climate change in Africa. IFPRI, Environment and Production Technology Division, International Food Policy Research Institute, Washington, DC.

25. Ghana Statistical Service (GSS) (2012) 2010 Population and Housing Census. Analytical Report, Northern Region

26. Abungba JA, Khare D, Pingale SM, Adjei KA, Gyamfi C, Odai SN (2020) Assessment of hydro-climatic trends and variability over the black volta basin in Ghana. Earth Syst Environ 4(4):739-755

27. Young G, Valdez EA, Kohn R (2009) Multivariate probit models for conditional claim-types. Insurance Math Econ 44(2):214-228

28. Deressa TT, Hassan RM, Ringler C, Alemu T, Yesuf M (2009) Determinants of farmers' choice of adaptation methods to climate change in the Nile Basin of Ethiopia. Global Environ Change 19(2):248-255

29. Chao-Ying JP, Lee KL, Ingersoll GM (2002) An introduction to logistic regression analysis and reporting. J Educ Res 96(1):3-14

30. Dumenu WK, Obeng EA (2016) Climate change and rural communities in Ghana: Social vulnerability, impacts, adaptations and policy implications. Environ Sci Policy 55:208-217

31. Kwadz GT, Kuwornu JK, Amadu IS (2013) Food crop farmers' willingness to participate in market-based crop insurance scheme: evidence from Ghana. Res Appl Econ 5(1),

32. Deressa T, Hassan RM, Ringler C (2008) Measuring Ethiopian farmers' vulnerability to climate change across regional states. 
International Food Policy Research Institute. Discussion Paper 00806:1-38

33. Apata TG, Samuel KD, Adeola AO (2009) Analysis of climate change perception and adaptation among arable food crop farmers in South Western Nigeria. In Contributed paper prepared for presentation at the International Association of Agricultural Economists' 2009 Conference, Beijing, China, August $16(22), 1-15$

34. Liu B, Xu M, Henderson M, Gong W (2004) A spatial analysis of pan evaporation trends in China, 1955-2000. J Geophys Res Atmos 109(D15).

35. Norton RD, Hazell PB (1986) Mathematical programming for economic analysis in agriculture. Macmillan

36. Nabikolo D, Bashaasha B, Mangheni MN, Majaliwa JGM (2012) Determinants of climate change adaptation among male and female headed Farm households in Eastern Uganda. Afr Crop Sci J 20(Suppl s2):203-212

37. Caviglia-Harris JL (2004) Household production and forest clearing: the role of farming in the development of the Amazon. Environ Dev Econ, pp 181-202.

38. Belay A, Recha JW, Woldeamanuel T, Morton JF (2017) Smallholder farmers' adaptation to climate change and determinants of their adaptation decisions in the Central Rift Valley of Ethiopia. Agric Food Security 6(1):1-13

39. Nyadzi E, Werners SE, Biesbroek R, Ludwig F (2020) Techniques and skills of indigenous weather and seasonal climate forecast in Northern Ghana. Clim Dev, 1-12.

40. Salvini G, Ligtenberg A, Van Paassen A, Bregt AK, Avitabile V, Herold M (2016) REDD+ and climate-smart agriculture in landscapes: a case study in Vietnam using companion modelling. J Environ Manage 172:58-70

41. Acquah S, Kendie S, Agyenim JB (2017) Determinants of rural farmers' decision to adapt to climate change in Ghana. Russ J Agric Socio-Econ Sci 2:195-204

42. Dumenu WK (2014) Climate change and rural communities in Ghana: Insight from social vulnerability assessment. In First National Forestry Conference, pp 16-18.

43. Fagariba CJ, Song S, Soule $S$ (2018) Factors influencing farmers' climate change adaptation in Northern Ghana: evidence from subsistence farmers in Sissala West, Ghana. J Environ Sci Manage, 21(1).

44. Gyapong AY (2021) Commodification of family lands and the changing dynamics of access in Ghana. Third World Q 1-19

45. Assan E, Suvedi M, Schmitt Olabisi L, Allen A (2018) Coping with and adapting to climate change: a gender perspective from smallholder farming in Ghana. Environments 5(8):86

46. Amsalu A, De Graaff J (2007) Determinants of adoption and continued use of stone terraces for soil and water conservation in an Ethiopian highland watershed. Ecol Econ 61(2-3):294-302

47. Maddison D (2006) The perception of and adaptation to climate change in Africa (CEEPA Discussion Paper No. 10). Centre for Environmental Economics and Policy in Africa, University of Pretoria, South Africa.

48. Tiwari KT, Rayamajhi S, Pokharel RK, Balla MK (2014) Determinants of the climate change adaptation in rural farming in Nepal Himalaya. Int J Multidisciplinary Curr Res 2:2321-3124

49. Ndamani F, Watanabe $T$ (2014) Influences of rainfall on crop production and suggestions for adaptation. Int J Agric Sci 5:367-374

50. Young G, Valdez EA, Kohn R (2009) Multivariate probit models for conditional claim-types. Insurance Math Econ 44(2):214-228.

51. Simtowe F, Zeller M (2006) The impact of access to credit on the adoption of hybrid maize in Malawi: an empirical test of an Agricultural Household Model under Credit Market Failure.
52. Below TB, Mutabazi KD, Kirschke D, Franke C, Sieber S, Siebert R, Tscherning K (2012) Can farmers' adaptation to climate change be explained by socio-economic household-level variables? Global Environ Change 22(1):223-235. https://doi.org/10. 1016/j.gloenvcha.2011.11.012

53. Aemro T, Mengistu K, Beyene T (2012) Climate change adaptation strategies of smallholder farmers: The case of Babile District, East Hararghe Zone of Oromiya Regional State of Ethiopia. J Econ Sustain Dev 3(14). ISSN 2222-1700 (Paper) ISSN 2222-2855.

54. Baethgen WE, Meinke H, Gimenez A (2003) Adaptation of agricultural production systems to climate variability and climate change: lessons learned and proposed research approach. In: Climate Adaptation. net conference "Insights and Tools for Adaptation: Learning from Climate Variability, pp 18-20.

55. Babbie E (2010) Research design. The practice of social research, 12th edn. Cengage Learning, Belmont, CA, USA, pp 90-123

56. Aryal JP, Farnworth CR, Khurana R, Ray S, Sapkota TB (2014) Gender dimensions of climate change adaptation through climate smart agricultural practices in India. Innovation in Indian Agriculture: Ways Forward. New Delhi: Institute of Economic Growth (IEG), New Delhi, and International Food Policy Research Institute (IFPRI), Washington, D.C.

57. Asafu-Adjaye J (2008) Factors affecting the adoption of soil conservation measures: a case study of Fijian cane farmers. J Agric Resource Econ 33(1):99-117

58. Baethgen WE, Meinke H, Gimenez A (2003) Variability and climate change: lessons learned and proposed research approach. In: Paper presented at Climate adaptation net conference insights and tools for adaptation: learning from climate variability, 18-20 November, 2003, Washington, D.C.

59. Velandia M, Rejesus RM, Knight TO, Sherrick BJ (2009) Factors affecting farmers' utilization of agricultural risk management tools: the case of crop insurance, forward contracting, and spreading sales. J Agric Appl Econ 41(1):107-123

60. O'Brien KL, Wolf J (2010) A values-based approach to vulnerability and adaptation to climate change. Wiley Interdisciplinary Rev Climate Change 1(2):232-242

61. Ojo TO, Baiyegunhi LJS (2020) Determinants of climate change adaptation strategies and its impact on the net farm income of rice farmers in south-west Nigeria. Land Use Policy 95:103946

62. Lin CTJ, Jensen KL, Yen ST (2005) Awareness of foodborne pathogens among US consumers. Food Qual Prefer 16:401-412

63. Belderbos R, Carree M, Diederen B, Lokshin B, Veugelers R (2004) Heterogeneity in R\&D cooperation strategies. Int J Ind Organ 22(8/9):1237-1263

64. Wooldridge M (2003) Reasoning about rational agents. MIT Press, Cambridge

65. Mulwa C, Marenya P, Kassie M (2017) Response to climate risks among smallholder farmers in Malawi: a multivariate probit assessment of the role of information, household demographics, and farm characteristics. Clim Risk Manage 16:208-221

66. Teklewold H, Kassie M, Shiferaw B, Köhlin G (2013) Cropping system diversification, conservation tillage, and modern seed adoption in Ethiopia: Impacts on household income, agrochemical use, and demand for labor. Ecol Econ 93:85-93

67. Stanturf JA, Warren ML, Charnley S Jr, Polasky SC, Goodrick SL, Armah F, Nyako YA (2011) Ghana Climate Change Vulnerability and Adaptation Assessment. US Agency for International Development, Washington

68. Kandlikar M, Risbey J (2000) Agricultural impacts of climate change: if adaptation is the answer, what is the question? Clim Change 45(3-4):529

69. Shiferaw B, Holden ST (1998) Resource degradation and adoption of land conservation technologies in the Ethiopian 
highlands: a case study in Andit Tid. North Shewa Agric Econ 18(3):233-247

70. Dolisca F, Carter DR, McDaniel JM, Shannon DA, Jolly CM (2006) Factors influencing farmers' participation in forestry management programs: a case study from Haiti. Forest Ecol Manage 236(2-3):324-331

71. Bayard B, Jolly CM, Shannon DA (2007) The economics of adoption and management of alley cropping in Haiti. J Environ Manage 84(1):62-70

72. Bekele W, Drake L (2003) Soil and water conservation decision behavior of subsistence farmers in the Eastern Highlands of Ethiopia: a case study of the Hunde-Lafto area. Ecol Econ 46(3):437-451

73. Glendinning A, Mahapatra A, Mitchell CP (2001) Modes of communication and effectiveness of agroforestry extension in eastern India. Human Ecol 29(3):283-305

74. Anderson A (2012) Climate change education for mitigation and adaptation. J Educ Sustain Dev 6(2):191-206

75. Anley Y, Bogale A, Haile-Gabriel A (2007) Adoption decision and use intensity of soil and water conservation measures by smallholder subsistence farmers in Dedo district. Western Ethiopia Land Degradation Dev 18(3):289-302

76. Tizale CY (2007) The dynamics of soil degradation and incentives for optimal management in the Central Highlands of Ethiopia. Doctoral dissertation, University of Pretoria.

77. Dittoh S, Snyder KA, Lefore N (2015) Gender policies and implementation in agriculture, natural resources and poverty reduction: Case study of Ghana's Upper East Region (Vol. 3). International Water Management Institute (IWMI). CGIAR Research Program on Water, Land and Ecosystems (WLE).

78. Denkyirah EK, Okoffo ED, Adu DT, Aziz AA, Ofori A (2016) Modeling Ghanaian cocoa farmers' decision to use pesticide and frequency of application: the case of Brong Ahafo Region. Springerplus 5(1):1113

79. Fisher-Vanden K, Wing IS, Lanzi E, Popp D (2011) Modeling climate change adaptation: Challenges, recent developments, and future directions. Boston University, Mimeographed paper

80. Mabe FN, Gifty S, Samuel D (2014) Determinants of choice of climate change adaptation strategies in northern Ghana. Res Appl Econ 6:75-94

81. Nyantakyi-Frimpong $\mathrm{H}$ (2017) Agricultural diversification and dietary diversity: a feminist political ecology of the everyday experiences of landless and smallholder households in northern Ghana. Geoforum 86:63-75

82. Milazzo A, Van De Walle D (2017) Women left behind? Poverty and headship in Africa Demography 54(3):1119-1145

83. Kabeer N (2002) Citizenship, affiliation and exclusion: perspectives from the South

84. Li Z, Cao Y, Tang J, Wang Y, Duan Y, Jiang Z, Qu Y (2020) Relationships between temporal and spatial changes in lakes and climate change in the saline-alkali concentrated distribution area in the Southwest of Songnen Plain, Northeast China, from 1985 to 2015. Water 12(12):3557

85. Few R, Tran PG (2010) Climatic hazards, health risk and response in Vietnam: case studies on social dimensions of vulnerability. Global Environ Change 20(3):529-538

86. Di Falco S, Veronesi M, Yesuf M (2011) Does adaptation to climate change provide food security? A micro-perspective from Ethiopia. Am J Agric Econ 93(3):829-846. https://doi.org/10.1093/ajae/ aar006

87. Ahmed A, Lawson ET, Mensah A, Gordon C, Padgham J (2016) Adaptation to climate change or non-climatic stressors in semiarid regions? Evidence of gender differentiation in three agrarian districts of Ghana. Environ Dev 20:45-58. https://doi.org/10. 1016/j.envdev.2016.08.002
88. Abdul-Razak M, Kruse S (2017) The adaptive capacity of smallholder farmers to climate change in the Northern Region of Ghana. Clim Risk Manag 17:104-122

89. Niang I, Ruppel OC, Abdrabo MA, Essel A, Lennard C, Padgham J, Urquhart P. Africa. In: Barros VR, Field CB, Dokken DJ, Mastrandrea MD, Mach KJ, Bilir TE, Chatterjee M, Ebi KL, Estrada YO, Genova RC, Girma B, Kissel ES, Levy AN, MacCracken S, Mastrandrea PR, White LL (eds) (2014) Climate change 2014: impacts, adaptation, and vulnerability. Part B: regional aspects. Contribution of Working Group II to the Fifth Assessment Report of the Intergovernmental Panel on Climate Change. Cambridge University Press, Cambridge, pp 1199-265

90. Juana JS, Kahaka Z, Okurut FN (2013) Farmers' perceptions and adaptations to climate change in Sub-Sahara Africa: a synthesis of empirical studies and implications for public policy in African agriculture. J Agric Sci 5(4):121-135

91. Ashby J, Kristjanson P, Thornton P, Campbell B, Vermeulen S, Wollenberg E (2012) CCAFS GENDER STRATEGY CGIAR Research Program on Climate Change, Agriculture and Food Security (CCAFS). Denmark, Copenhagen

92. Kabeer N (2002) Citizenship and the boundaries of the acknowledged community: identity, affiliation and exclusion

93. Fosu-Mensah BY, Vlek PLG, MacCarthy DS (2012) Farmers' perceptions and adaptation to climate change: a case study of Sekyeredumase district in Ghana. Environ Dev Sustain 14:495-505

94. Korir JC (2019). Level of awareness about climate change among the Pastoral Community.

95. Oruonye ED (2011) An assessment of the awareness of the effects of climate change among students of tertiary institutions in Jalingo Metropolis, Taraba State, Nigeria. J Geogr Reg Plan 4(9):513-517

96. Tangonyire DF, Akuriba GA (2020) Socioeconomic factors influencing farmers'specific adaptive strategies to climate change in Talensi district of the Upper East Region of Ghana. Ecofeminism and Climate Change.

97. Deressa TT, Hassan RM, Ringler C (2011) Perception of and adaptation to climate change by farmers in the Nile basin of Ethiopia. J Agric Sci 49(1):23

98. Nhemachena C, Hassan R (2007). Micro-level analysis of farmers' adaption to climate change in Southern Africa. Intl Food Policy Res Inst.

99. Cameron C (2011) Climate change financing and aid effectiveness: Ghana case study. Available online: http://www.agulhas. co.uk

100. Adu-Boahen K, Dadson IY, Halidu MA (2019) Climatic variability and food crop production in the bawku west district of the upper east region of Ghana. Ghana J Geo 11(1):103-123

101. Wooldridge $J$ (2010) Econometric analysis of cross section and panel data, 2nd edn. The MIT Press, Cambridge

102. Nyantakyi-Frimpong $\mathrm{H}$, Bezner-Kerr $\mathrm{R}$ (2015) The relative importance of climate change in the context of multiple stressors in semi-arid Ghana. Global Environ Change 32(2015):40-56. https:// doi.org/10.1016/j.gloenvcha.2015.03.003

103. Sundstrom A, Mccright AM (2014) Gender differences in environmental concern among Swedish citizens and politicians. Environ Pol 23(6):1082-1095

104. Nyadzi E (2016) Climate variability since 1970 and farmers' observations in Northern Ghana. Sustain Agric Res 5(526-2016-37880).

105. Nyadzi E, Werners ES, Biesbroek R, Long PH, Franssen W, Ludwig $F$ (2019) Verification of seasonal climate forecast toward hydroclimatic information needs of rice farmers in Northern Ghana. Weather Clim Soc 11(1):127-142

106. Solomon E, Edet OG (2018) Determinants of climate change adaptation strategies among farm households in delta state, Nigeria. Current Investigations in Agriculture and Current Research. Lupine Publishers, LLC, vol. 5(3):663-668 
107. Zhenmin L, Espinosa P (2019) Tackling climate change to accelerate sustainable development. Nat Clim Change 9(7):494-496

108. Yu L, Hurley T, Kliebenstein J, Orazen P (2008) Testing for complementarity and substitutability among multiple technologies: The case of US Hog farms. Working Paper No. 08026, lowa State University, Department of Economics, Ames, IA.

109. Manyanhaire IO (2015) Integrating indigenous knowledge systems into climate change interpretation: perspectives relevant to Zimbabwe. Greener J Educ Res 5:27-35

110. Trinh TQ, Rañola RF Jr, Camacho LD, Simelton E (2018) Determinants of farmers' adaptation to climate change in agricultural production in the central region of Vietnam. Land Use Policy 70:224-231

111. Nabikolo D, Bashaasha B, Mangheni MN, Majaliwa JGM (2012) Determinants of climate change adaptation among male and female headed farm households in Eastern Uganda. Afr Crop Sci J 20(Suppl s2): 203-212

112. Brick K, Visser M (2015) Risk preferences, technology adoption and insurance uptake: a framed experiment. J Econ Behav Organ 118:383-396

113. Gender FAO (2017) Land Rights Database. R. cp.

114. Afriyie K, Ganle JK, Santos E (2017) The floods came and we lost everything: Weather extremes and households' asset vulnerability and adaptation in rural Ghana. Clim Dev, 1-16. https://doi.org/ 10.1080/17565529.2017.1291403
115. Thinda KT, Ogundeji AA, Belle JA, Ojo TO (2020) Determinants of relevant constraints inhibiting farmers' adoption of climate change adaptation Strategies in South Africa.

116. Ojo T, Baiyegunhi L (2018) Determinants of adaptation strategies to climate change among rice farmers in Southwestern Nigeria: a multivariate probit approach.

117. Ali A, Erenstein $O$ (2016) Irrigation water saving through adoption of direct rice sowing technology in the Indo-Gangetic Plains: empirical evidence from Pakistan. Water Pract Technol 11(3):610-620

118. Wondimagegn $M$, Bekabil F, Jema $H$ (2011) Patterns, trend and determinants of crop diversification: empirical evidence from smallholders in Eastern Ethiopia. J Econ Sustain Dev 2(8):78-89

119. Partey ST, Dakorah AD, Zougmoré RB, Ouédraogo $M$, Nyasimi $M$, Nikoi GK, Huyer S (2020) Gender and climate risk management: evidence of climate information use in Ghana. Clim Change 158(1):61-75

Publisher's Note Springer Nature remains neutral with regard to jurisdictional claims in published maps and institutional affiliations. 